\title{
Changes in Lymphocyte Activity after Thermal Injury
}

\author{
THE ROLE OF SUPPRESSOR CELLS
}

\author{
CARol L. Miller and Christopher C. BAKER, Trauma Center, Departments of Surgery \\ and Microbiology-Immunology, University of California, San Francisco, San \\ Francisco General Hospital, San Francisco, California 94110
}

\begin{abstract}
A B S T R A C T The high incidence of fatal septicemia associated with severe thermal injury is believed to result from a loss of immunocompetence. To detect burn-mediated immune defects, lymphocyte function in peripheral blood leukocytes from 18 individuals sustaining $20-80 \%$ full thickness thermal burns was investigated. We examined the kinetics of the mitogen responses, the development of suppressive activity, and the correlation of mononuclear cell functional abnormalities with the incidence of sepsis. Patients were divided into three groups corresponding to their clinical course. The phytohemagglutinin responses of Ficoll-Hypaque purified leukocytes from eight of these patients (group III) were normal at day 1-2 after injury, but were significantly depressed (mean $16 \%$ of normal) at days 5-10 after injury. All of these group III patients experienced multiple, severe, septic episodes, and septic mortality was $75 \%$. The other 10 burned individuals showed either augmented (group II) or unaltered (group I) mitogen responsiveness.

Concomitant with evaluation of their mitogen responses, the cells of burn patients were assessed for development of suppressive activity by addition to ongoing normal mixed leukocyte reactions (MLR). Only the addition of mononuclear cells with depressed phytohemagglutinin responsiveness (group III) significantly decreased MLR proliferation (mean $80 \%$ reduction) by the previously highly responsive, normal MLR combinations. Addition of cells from group III burn patients collected immediately after injury had no suppressive effect. Addition of cells from patients in group I or II or of normal individual's cells had no suppressive effect. These experimental results strongly suggest that a suppressive mononuclear cell is at least partially responsible for the decreased immunocompetence of burn patients.
\end{abstract}

Received for publication 27 February 1978 and in revised form 27 September 1978.

\section{INTRODUCTION}

Since the refinement of modern fluid resuscitation and respiratory care techniques, sepsis has emerged as the major cause of mortality after thermal injury $(1,2)$. Reduction of immunocompetence induced by thermal injury has been suggested as mediating an increased susceptibility to infection. There have been many reports of impairment to various parameters of immune function after thermal injury (3-5). The immune dysfunctions noted in burn patients could result from aberrations in any or all of the three general types of cells involved in immune responses, i.e., bursa equivalent cells, thymus-derived ( $T$ ) cells, or the heterogeneous population of monocytes $(\emptyset) .{ }^{1}$ The activity of bursa equivalent cells appears to be only slightly affected by thermal injury (6-8). In contrast, both $\emptyset$ and T-cell defects have been attributed to thermal trauma ( 5 , 8-12). It has been suggested that suppressor $\mathrm{T}$ cells play a role in the decreased immunocompetence that appears after burns $(13,14)$. The activation of suppressor cells, however, has not been directly demonstrated in the mononuclear populations of burn patients. This study was undertaken to determine whether or not suppressive activity could be demonstrated in the mononuclear cell populations of patients after major thermal injury.

Earlier investigations have shown that the phytohemagglutinin (PHA) responses of leukocytes from burn patients increased concomitant with the loss of immune functions $(15,16)$. Because PHA is a T-cell mitogen, it was possible that these increased PHA responses represented PHA-responsive suppressor $\mathrm{T}$

\footnotetext{
${ }^{1}$ Abbreviations used in this paper: $\emptyset$, heterogeneous population of monocytes; MLR, mixed leukocyte reaction(s); $\mathrm{P}$, patient; PHA, phytohemagglutinin; $\mathrm{P}_{\mathrm{m}}$, patient mitomycin treated; $\mathbf{R}$, normal responders untreated; $\mathbf{R}_{m}$, normal responders mitomycin treated; $S_{m}$, normal stimulator; ${ }^{3} \mathrm{H}-\mathrm{TdR}$, tritiated thymidine.
} 
cells $(17,18)$. This hypothesis would explain both the data showing loss of immunocompetence and the data showing simultaneous increases in mitogen responsiveness. Preliminary to the investigations of suppressive activity, the PHA responses of Ficoll-Hypaque purified mononuclear cells of acutely burned patients were characterized at various times after injury. It was found that the cells from a small subset of patients with full thickness burns had decreased ability to respond to PHA. These were the same patients who also had repeated life-threatening episodes of sepsis and appeared unable to contain infections. The mortality of this patient group was $75 \%$ due to sepsis. In contrast, cells from severely burned patients who overcame infectious episodes showed greatly augmented rather than decreased PHA responses.

Mononuclear cells from the acutely burned patients were examined for their ability to reduce an ongoing "one-way" mixed leukocyte reaction(s) (MLR) between cells from two normal individuals. Leukocytes from thermally injured patients have been shown to have decreased ability to respond or stimulate in a MLR response with normal cells $(19,20)$. However, these data can be questioned because no HLA typing was performed. In this study, known, highly responsive, normal combinations were used in a MLR system as indicators of suppression. Only an addition of cells from those burn patients who had decreased PHA responsiveness could reduce the proliferation seen in cultures of these ongoing, normal MLR. These data may be interpreted as indicating that suppressor cells appear in the mononuclear cell populations of some burn patients and are responsible for decreasing the immunocompetence of these patients.

\section{METHODS}

Human subjects. Peripheral blood from 14 adult male patients, ages $24-76$, and 4 female patients, ages $42-74$, with moderate to severe thermal injury were examined every 2-4 d for the first $2 \mathrm{wk}$ after injury and weekly thereafter up to time of discharge. Injuries ranged in severity from 20 to $80 \%$ third degree burns with 12 of these patients having moderate to severe inhalation injury requiring ventilation. Eight patients had severe septic episodes, and six of these patients succumbed to septicemia. Five additional patients experienced minor septic episodes. In retrospect, the patients were divided into three groups according to their clinical course. Group I consisted of those patients without detectable clinical infectious complications. Group II consisted of patients who experienced septic episodes that were responsive to antibiotics. Group III consisted of patients who experienced severe septicemia with multiple organisms isolated from various tissues. These individuals responded poorly to antibiotic therapy, and the majority (75\%) succumbed to fatal septicemia.

27 normal males, ages $22-52$, and 14 normal females, ages 21-40, were used as controls in experiments examining mitogen responses to PHA. In addition, these individuals were screened using the one-way MLR (21). 10 normal high responders untreated $(R)$ were selected from the volunteer group and paired with previously identified stimulators. The one-way MLR between these highly reactive responderstimulator combinations was then used as an indicator system to detect the suppressive activity of the burn patients' leukocytes.

Isolation of mononuclear cells. $10-20 \mathrm{ml}$ of blood are collected from patients and volunteers in sterile heparinized tubes. The samples are diluted 1:3 in RPMI-1640 (Flow Laboratories, Inc., Rockville, Md.), and mononuclear cells are isolated by centrifugation on Ficoll-Hypaque density gradients (Ficoll, Pharmacia Fine Chemicals, Div. of Pharmacia Inc., Piscataway, N. J.; Hypaque, Winthrop Laboratories Sterling Drug Co., New York) (22). Purified mononuclear cells are then washed three times $\left(1,700 \mathrm{rpm}\right.$ for $15 \mathrm{~min}$ at $\left.4^{\circ} \mathrm{C}\right)$ in Hanks' balanced salt solution supplemented with $5 \%$ fetal bovine serum and $1 \%$ penicillin/streptomycin. Mononuclear cell populations from burn patients are divided into two groups. One group is examined for mitogen responsiveness, the other for suppressive activity.

Mitogen responses. The first group of cells is suspended in RPMI-1640 media supplemented with $7 \%$ heat-inactivated FBS, $1 \%$ penicillin/streptomycin, glutamine, and $0.1 \mathrm{mg} / \mathrm{ml}$ gentamicin. Triplicate cultures are established using $2 \times 10^{5}$ untreated cells from burn patients or normal controls in microplates (Microtest II, Falcon 3040 Falcon Plastics, Div. of BioQuest, Oxnard, Calif.). To these cultures, $0.1 \mathrm{ml}$ of PHA (Burroughs Wellcome Co., Research Triangle Park, N. C.) is added at $0.1,0.2$, and $0.4 \mu \mathrm{g} /$ culture, and a control line without PHA is used. Total culture volume is $0.2 \mathrm{ml}$. The cultures are then incubated at $37^{\circ} \mathrm{C}$ in an atmosphere of $7 \% \mathrm{O}_{2}, 10 \% \mathrm{CO}_{2}$, and $83 \% \mathrm{~N}_{2}$ (11). After $48 \mathrm{~h}$ of incubation, the cultures are pulsed with $1 \mu \mathrm{Ci}$ of tritiated thymidine $\left({ }^{3} \mathrm{H}-\mathrm{TdR}\right)$. After an additional $24 \mathrm{~h}$ of culture, the cells are harvested with a Multiple Automated Sample Harvest Unit (MASH II, Microbiological Associates, Walkersville, Md.) on Whatman No. 1 glass fiber paper (Whatman, Inc., Clifton, N. J.). Harvested cells are washed successively with $0.85 \%$ saline, $5 \%$ trichloroacetic acid (TCA), and absolute methanol. Scintillation fluid (toluene and ominfluor) is added, and cell incorporation of ${ }^{3} \mathrm{H}-\mathrm{TdR}$ is counted on a Packard liquid scintillation counter (Packard Instrument Co., Inc., Downers Grove, Ill.).

MLR experiments. The second group of Ficoll-Hypaque isolated cells is examined in MLR experiments $(21,23)$. Normal stimulator $\left(S_{m}\right)$, normal responder mitomycin treated $\left(R_{m}\right)$, and patient cells that are treated with mitomycin $C$ (Sigma Chemical Co., St. Louis, Mo.) at $25 \mu \mathrm{g} / \mathrm{ml}$ for $30 \mathrm{~min}$ at $37^{\circ} \mathrm{C}(21)$. The mitomycin-treated cells are washed three times in supplemented Hanks' balanced salt solution, suspended in supplemented RPMI media, and cultured in triplicate with a total of $4 \times 10^{5}$ cells $/ 0.2 \mathrm{ml}$. The experimental design compares the effect of the burn patient's mitomycintreated $\left(P_{m}\right)$ and(or) untreated $(P)$ leukocytes on an ongoing normal one-way MLR $\left(S_{m} \times R \times P_{m}\right.$ and $\left.S_{m} \times R \times P\right)$. Total cell numbers are held constant at $4 \times 10^{5}$ in all cultures. Each assay contains triplicate cultures consisting of the combinations found in Table I. Cultures were maintained for $5 \mathrm{~d}$, then pulsed and harvested $24 \mathrm{~h}$ later.

\section{Data calculation}

Mitogen responses. Extensive examination of normal human mononuclear cells revealed a wide variation in normal response levels for cells from different individuals (Fig. 1). Consequently, comparison between $\Delta$ counts per minute of patients and those of normal groups tends to obscure all but the most dramatic changes. Determining the normal mitogen response level of each patient allows detection of more subtle 
TABLE I

Experimental Design of MLR for Detection of Suppression

\begin{tabular}{|c|c|c|c|c|c|c|}
\hline \multirow[b]{2}{*}{ Experimental cultures } & \multicolumn{6}{|c|}{ Cells per culture* } \\
\hline & $\mathbf{R} \times \mathbf{S}_{\mathbf{m}} \times \mathbf{R}_{\mathbf{m}}$ & $\mathbf{R} \times \mathbf{P}_{\mathbf{m}} \times \mathbf{R}_{\mathbf{m}}$ & $\mathbf{R} \times \mathbf{S}_{\mathrm{m}} \times \mathbf{P}_{\mathrm{m}}$ & $\mathbf{R} \times \mathbf{S}_{\mathbf{m}} \times \mathbf{P}$ & $\mathbf{P} \times \mathbf{S}_{\mathrm{m}} \times \mathbf{P}_{\mathrm{m}}$ & $\mathbf{P} \times \mathbf{R}_{\mathbf{m}} \times \mathbf{P}_{\mathbf{m}}$ \\
\hline$S_{m}$ & $1 \times 10^{5}$ & & $1 \times 10^{5}$ & $1 \times 10^{5}$ & $1 \times 10^{5}$ & \\
\hline $\mathbf{R}$ & $2 \times 10^{5}$ & $2 \times 10^{5}$ & $2 \times 10^{5}$ & $2 \times 10^{5}$ & & \\
\hline $\mathbf{R}_{\mathbf{m}}$ & $1 \times 10^{5}$ & $1 \times 10^{5}$ & & & & $2 \times 10^{5}$ \\
\hline $\mathbf{P}$ & & & & $1 \times 10^{5}$ & $1 \times 10^{5}$ & $1 \times 10^{5}$ \\
\hline$P_{m}$ & & $1 \times 10^{5}$ & $1 \times 10^{5}$ & & $2 \times 10^{5}$ & $1 \times 10^{5}$ \\
\hline Control cultures ...... & $\mathrm{S}_{\mathrm{m}} \times \mathbf{R}_{\mathrm{m}} \times \mathrm{P}_{\mathrm{m}}$ & $\mathbf{R}_{\mathrm{m}} \times \mathbf{P}_{\mathbf{m}}$ & $\mathbf{R} \times 2 \mathrm{~S}_{\mathrm{m}}$ & $\mathbf{P}_{\mathrm{m}} \times \mathrm{S}_{\mathrm{m}}$ & $\mathrm{R}$ alone & $P$ alone \\
\hline$S_{m}$ & $1 \times 10^{5}$ & & $2 \times 10^{5}$ & $2 \times 10^{5}$ & & \\
\hline $\mathbf{R}$ & & & $2 \times 10^{5}$ & & $2 \times 10^{5}$ & \\
\hline $\mathbf{R}_{\mathbf{m}}$ & $2 \times 10^{5}$ & $2 \times 10^{5}$ & & & & \\
\hline $\mathbf{P}$ & & & & & & $2 \times 10^{5}$ \\
\hline $\mathbf{P}_{\mathrm{m}}$ & $1 \times 10^{5}$ & $2 \times 10^{5}$ & & $2 \times 10^{5}$ & & \\
\hline
\end{tabular}

* Total cell numbers are maintained at $4 \times 10^{5} /$ culture by addition of mitomycin-treated cells.

variations. Examination of the mitogen response level of longterm surviving patients established that at 1-2 $\mathrm{d}$ after burn the mitogen response of patients' cells was normal. Although any two individual patients may have very different original mitogen response levels in total counts per min, the initial response is normal and returns to this original level after recovery. Cells from the same normal individuals were repeatedly tested, and their mitogen responses showed a maximum variation of $11 \%$. Consequently, a variation from initial mitogen response levels of $33 \%$ was considered signifi-

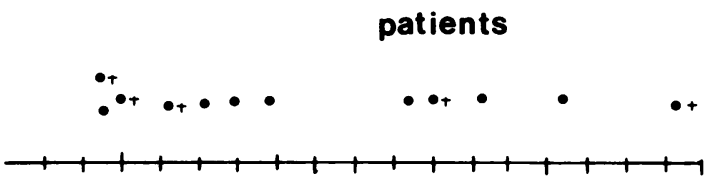

\section{normals}

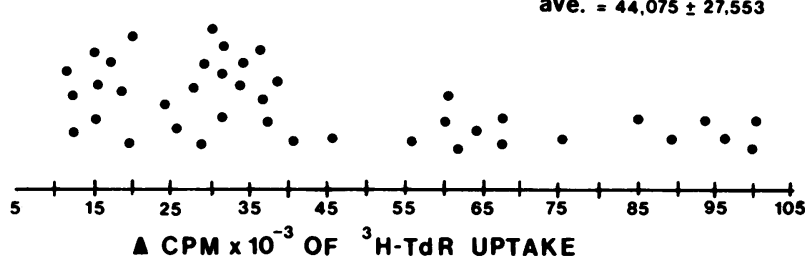

Figure 1 Nonbinomial distribution of normal individual's and burn patients' PHA responses. Each data point represents the average of 2-9 separate experiments measuring the proliferation of a normal individual's Ficoll-Hypaque purified mononuclear cells to $1 \mu \mathrm{g} /$ culture of PHA-P. Data are presented as increased incorporation of ${ }^{3} \mathrm{H}-\mathrm{TdR}$ in counts per minute after PHA stimulation as compared to unstimulated cultures with background substracted. Normals' backgrounds never exceeded $1,000 \mathrm{cpm}$. The average (ave.) of 41 normal individuals' PHA response is presented with $1 \mathrm{SD}$. The initial PHA response of burn patients' mononuclear cells at $1-2 \mathrm{~d}$ after injury are compared to the normals. Burn patients background responses never exceeded $3,000 \mathrm{cpm}$. The crosses represent patients who succumbed to septicemia. cant at the 0.01 levels. Patient data, therefore, were calculated and compared as a percentage of the original response $1-2 \mathrm{~d}$ after burn. Background counts per minute (cultured without PHA) which never exceeded $4,000 \mathrm{cpm}$, were subtracted from all data. Cells from normal individuals were included in each assay as a check on system stability.

MLR experiments. MLR results are expressed as percentage of suppression of the normal one-way $\operatorname{MLR}\left(S_{m} \times R\right)$. Percentage of suppression was calculated with the following formulas: $(a)$ percentage of suppression by mitomycin-treated patient cells equal $\left[\left(\mathbf{R} \times \mathbf{S}_{\mathrm{m}} \times \mathbf{R}_{\mathrm{m}}\right)+\left(\mathbf{R} \times \mathbf{R}_{\mathrm{m}} \times \mathbf{P}_{\mathrm{m}}\right)-(\mathbf{R}\right.$ $\left.\left.\times S_{m} \times P_{m}\right) /\left(R \times S_{m} \times R_{m}\right)+\left(R \times P_{m} \times R_{m}\right)\right] \times 100$; (b) percentage of suppression by untreated patient cells equal $\left[\left(\mathbf{R} \times \mathbf{S}_{\mathbf{m}} \times \mathbf{R}_{\mathrm{m}}\right)+\left(\mathbf{R} \times \mathbf{P}_{\mathrm{m}} \times \mathbf{R}_{\mathrm{m}}\right)+\left(\mathbf{P} \times \mathrm{S}_{\mathbf{m}} \times \mathbf{P}_{\mathbf{m}}\right)+\left(\mathbf{P} \times \mathbf{R}_{\mathbf{m}}\right.\right.$ $\left.\times P_{m}\right)-\left(R \times S_{m} \times P\right) /\left(R \times S_{m} \times R_{m}\right)+\left(R \times P_{m} \times R_{m}\right)+(P$ $\left.\left.\times S_{m} \times P_{m}\right)+\left(P \times R_{m} \times P_{m}\right)\right] \times 100$ (see Table I). These formula take into account the fact that the selected high responder normal may be massively stimulated by the patient cells. Significance of the data was calculated with the Wilcoxon test for nonparametric paired data.

\section{RESULTS}

The PHA responses of mononuclear cells from 18 burn patients were examined at various days after injury, and $0.1 \mu \mathrm{g}$ PHA was determined as the optimal concentration. Data comparing PHA responses of the burn patients appeared to fall into three categories which correlated with their subsequent clinical courses. Mononuclear cells from all burn patients who later experienced massive infectious complications had dramatically decreased PHA responses appearing at 4-6 d after injury. This patient type was subsequently categorized as group III. Six of these group III patients $(75 \%)$ succumbed to septicemia. The data from three of the burn patients who had terminal septic episodes are illustrated in Fig. 2. After initially losing their proliferative capacity, cells from some of these patients then experienced a slight rally in responsiveness, followed by a final dramatic decline in response. 


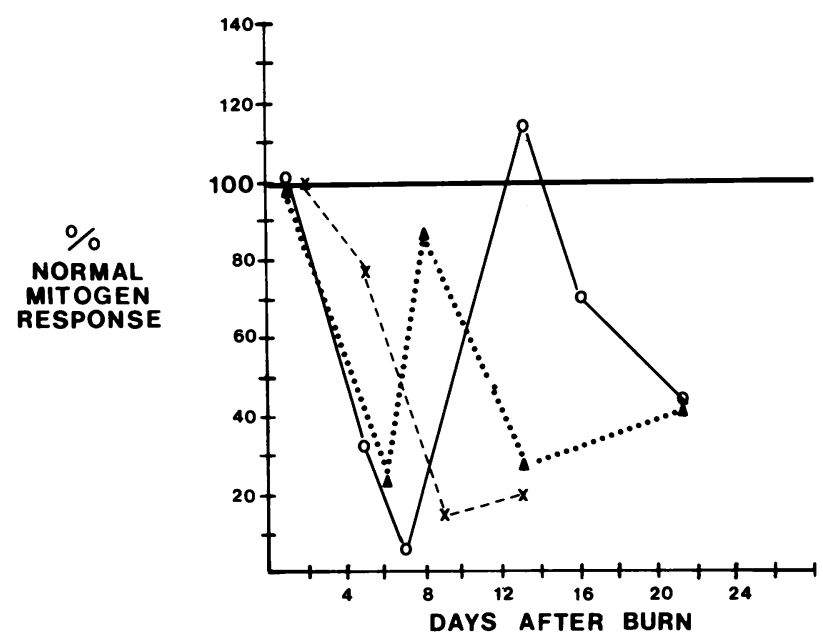

FIgURE 2 Loss of PHA responsiveness by mononuclear cells from severely burned patients. The PHA stimulated proliferation of burn patients' cells collected at various days after injury was assessed. The data are expressed as percent of ${ }^{3} \mathrm{H}$ TdR incorporation in counts per minute at $1-2 \mathrm{~d}$ after injury.

Loss of mitogen responsiveness preceded any clinical evidence of sepsis by 3-5 d. At no point was the PHA response of the six group III burn patients who eventually succumbed to infections significantly increased above their base-line PHA response.

PHA responses of the two group III patients who survived repeated severe septic episodes were also severely depressed during the 4- to 7-d after burn period (Fig. $3 a$ ). In contrast to the fatally injured individuals, however, the cells of these patients showed a 280-310\% increase in PHA responsiveness at day 15 after injury. This increased PHA response persisted for 5-20 d. When the responses of these individuals were measured at 52-72 d after injury, however, they varied only $3 \%$ from their base-line mitogen response level.

Group II included those patients who experienced clinically detectable infections which responded to antibiotic therapy. These patients' mononuclear cells exhibited a prolonged elevation of their PHA response, but no initial depression of mitogen responsiveness (Fig. 3b). Group I was comprised of those burn patients who had less acute injury and a relatively uneventful clinical course. Two of these patients showed a transient significant increase in PHA responsiveness which returned to normal by $15 \mathrm{~d}$ after injury as exemplified in Fig. $3 c$. Three patients showed no significant change in their PHA response level throughout their clinical course (Fig. $3 d$ ). These data are summarized in Table II. The PHA response of cells from a normal individual was simultaneously assessed in every patient assay as a system control.

Correlation of PHA depression to suppressor cell activity. The ability of mononuclear cells from burn
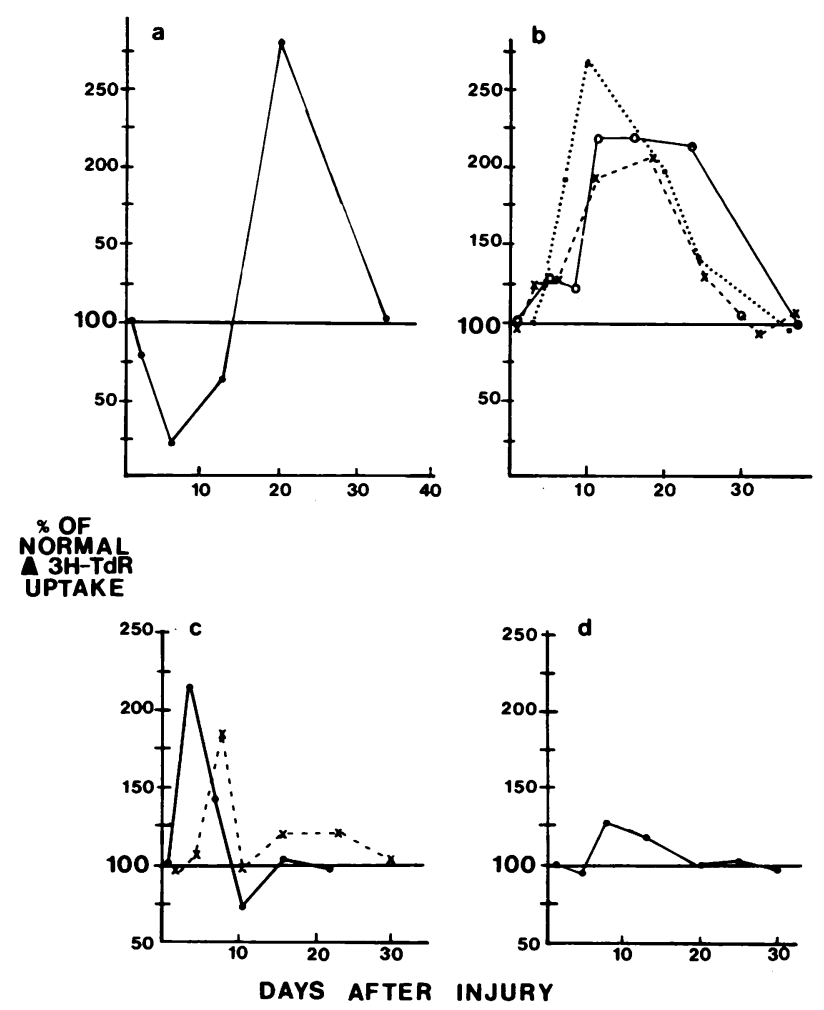

Figure 3 Varied PHA response patterns of mononuclear cells from different burn patients. (a) PHA response of 2 $\times 10^{5}$ mononuclear cells from patient who survived severe sepsis. (b) PHA response pattern of cells from three patients who had moderate septic episodes. (c) PHA response over time after injury of cells from two sepsis-free burn patients. $(d)$ PHA response pattern of severely burned individual who had a sepsis-free clinical course. Data are expressed as a percentage of average counts per minute ${ }^{3} \mathrm{H}-\mathrm{TdR}$ at $1-2 \mathrm{~d}$ and $>40 \mathrm{~d}$ after injury.

patients to suppress a normal ongoing MLR was assessed by coculturing them with one of 12 previously selected, highly responsive MLR combinations of stimulator and responder cells from normal volunteers. Addition of mononuclear cells from group I or II burned patients either augmented or had no effect on proliferation by normal, high responder, MLR combinations. In striking contrast, addition of mononuclear cells from those severely injured individuals whose PHA response were depressed (group III), significantly suppressed proliferation by cultures of the normal high responder combinations (Table III). An additional patient tested only once, had cells that suppressed the normal MLR combinations $60 \%$. This patient, however, died $8 \mathrm{~d}$ after injury and no further data were obtained.

Appearance of the suppressive activity of mononuclear cells from the group III burn patients was time related. As illustrated in Fig. 4, mononuclear cells collected at $1 \mathrm{~d}$ after burn had no ability to reduce MLR proliferation in cultures of the high responder combina- 
TABLE II

Correlation of lymphocyte immunological parameters 4-7 d after Thermal Injury to Clinical Course

\begin{tabular}{|c|c|c|c|c|c|c|}
\hline & $\begin{array}{l}\text { Patients } \\
\text { and age }\end{array}$ & $3^{\circ *}$ & $2^{\circ}$ & Clinical courset & $\begin{array}{l}\text { Maximum variation } \\
\text { of patients' normal } \\
\text { PHA response } \S\end{array}$ & $\begin{array}{c}\text { Average } \\
\text { suppression } \\
\text { of normal MLR }\end{array}$ \\
\hline & & & $\%$ & & $\%$ & $\%$ \\
\hline \multirow[t]{4}{*}{ Group I } & $\mathrm{J}-42$ & 2 & 30 & No sepsis discharged day 28 & +43 & 8 \\
\hline & $\mathrm{H}-45$ & 2 & 28 & No sepsis discharged day 35 & +86 & 0 \\
\hline & $\mathrm{T}-24$ & 50 & - & No sepsis discharged day 26 & +25 & 20 \\
\hline & $M-21$ & 25 & 5 & No sepsis discharged day 60 & +48 & 0 \\
\hline \multirow[t]{5}{*}{ Group II } & G-43 & 20 & 5 & $\begin{array}{l}\text { Moderate Escherichia coli sepsis still hospitalized } \\
\text { day } 78\end{array}$ & +300 & 33 \\
\hline & C-76 & 3 & 30 & Moderate Staphylococcus sepsis discharged day 85 & +208 & 19 \\
\hline & R-29 & 10 & 65 & Mild Staphylococcus sepsis discharged day 80 & +220 & 7 \\
\hline & Z-21 & 2 & 25 & $\begin{array}{l}\text { Moderate Staphylococcus sepsis still hospitalized } \\
\text { day } 65\end{array}$ & +180 & 0 \\
\hline & W-35 & 15 & 25 & Moderate Staphylococcus sepsis discharged day 93 & +308 & 20 \\
\hline \multirow[t]{8}{*}{ Group III } & $\mathrm{L}-45$ & 60 & - & $\begin{array}{l}\text { Severe Staphylococcus aureus, Pseudomonas sepsis, } \\
\text { succumbed }\end{array}$ & -98 & 60 \\
\hline & $\mathrm{N}-25$ & 45 & $\left(15 \%, 4^{\circ}\right)$ & Severe Staphylococcus Klebsiella sepsis, succumbed & -94 & 71 \\
\hline & D-37 & 60 & - & Severe Serratia, Staphylococcus sepsis, succumbed & -83 & 74 \\
\hline & $A-47$ & 35 & 7 & Severe Staphylococcus sepsis, succumbed & -84 & 53 \\
\hline & Q-66 & 20 & 15 & $\begin{array}{l}\text { Severe Pseudomonas, Staphylococcus sepsis, } \\
\text { succumbed }\end{array}$ & -85 & 65 \\
\hline & V-20 & 15 & 65 & $\begin{array}{l}\text { Severe Pseudomonas, Staphylococcus sepsis, } \\
\text { succumbed }\end{array}$ & -82 & 62 \\
\hline & E-58 & 42 & 10 & $\begin{array}{l}\text { Severe Proteus, Staphylococcus and Klebsiella } \\
\text { sepsis, still hospitalized }\end{array}$ & -85 & 61 \\
\hline & P-25 & 80 & - & $\begin{array}{l}\text { Severe Candida and Staphylococcus sepsis, } \\
\text { discharged day } 97\end{array}$ & -79 & 75 \\
\hline
\end{tabular}

* Percentage of body surface covered by full or partial thickness burn.

† Severe sepsis, isolation of organism from more than one organ source resistive to antibiotic therapy; moderate sepsis, isolation of organism or febrile period but responsive to antibiotic therapy.

$\$$ Response to $1 \mu \mathrm{g} /$ culture PHA patients'. Results expressed as percentage of 1-2 d $\Delta$ counts per minute response.

Average suppression caused by patient cells collected at 4 and $6 \mathrm{~d}$ or 5 and $7 \mathrm{~d}$ to normal one-way MLR expressed as percentage reduction of ${ }^{3} \mathrm{H}-\mathrm{TdR}$ incorporation.

tions. These same patients' cells collected at 5 or $8 \mathrm{~d}$ after injury exhibited highly significant suppressive activity. The suppressive activity disappeared at $13 \mathrm{~d}$ after injury only to reappear subsequently during recurrent septic episodes. The initial appearance of this suppressive activity, however, predated any clinical evidence of sepsis by several days.

The onset time of the ability of the patients' cells to suppress a normal MLR was compared to the time period of the cells' PHA response depression. As can be seen in Table II, the advent of the suppressive activity correlates with the period of depressed PHA responsiveness. Patients with no significant suppression also had only transient variations in their PHA response. Patients with augmented PHA responses had a variable degree of suppressive activity. None of the cells from group II patients had suppressive activity that was significant at the 0.01 level.
Reliability of MLR system for detecting suppression. The proliferative responses of the partial reactions taking place in separate cultures were summed and compared to the proliferation in the combined $\left(R \times S_{m}\right.$ $\times P)$ culture. This comparison could be giving artifactual suppression because some of the separate cell combinations may be able to respond at a higher level than the three cell mixtures. To control for this possibility, mononuclear cells from normals were added to different high responder MLR combinations. As can be seen in Table IV, the addition of normal cells, group I cells, or most group II cells resulted in observed responses that were not significantly different from those predicted by summing the partial reactions. It was also found that addition of group III cells collected immediately after injury similarly did not produce a significant decrease in the observed MLR proliferation. Correlation of appearance of suppressive activity to 
TABLE III

Effect* of Added Mononuclear Cells $\$$ from Groups III $\$$ Burn Patients on Normal High Responder MLR

\begin{tabular}{cccc}
\hline Patient & Partial reactions' & Observed & Suppression \\
\hline & $\Delta c p m$ & $\Delta c p m$ & $\%$ \\
D & 11,814 & 2,692 & 78 \\
N & 16,010 & 4,250 & 73 \\
P & 14,033 & 3,202 & 77 \\
A & 25,944 & 12,614 & 54 \\
L & 15,756 & 6,008 & 62 \\
V & 14,652 & 3,645 & 75 \\
Q & 19,562 & 7,230 & 63 \\
E & 14,355 & 4,480 & 69 \\
\hline
\end{tabular}

* Effect of adding $10^{5}$ burn cells or $10^{5}$ mitomycin-treated responder cells to one way MLR.

† Burn patients' mononuclear cells collected at 4-7 d after injury.

$\$$ Group III consists of those burn patients who later developed acute sepsis (six out of eight succumbed).

" $R \times S_{m}+R \times P_{m}+P \times R_{m}+P \times S_{m}$.

I Average $\Delta$ counts per minute triplicate cultures $\left(R \times S_{m} \times P\right)$.

loss of immunocompetence. Group III burn patients were examined for their ability to stimulate and respond to normal individuals' cells. At the time that suppressive activity of these cells was maximal, they were uniformly poor responders in one-way MLR (Table V). This poor response was not a result of genetic similarity between the burn patients' cells and the mitomycintreated normal stimulator cells because group III burn

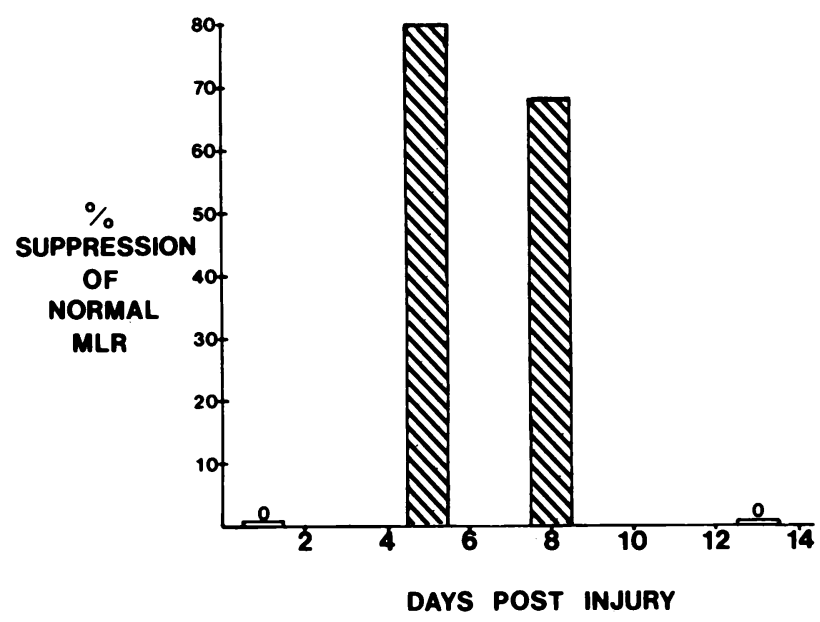

FIGURE 4 Development of suppressive activity in the mononuclear cells of burn patients. The effect of adding $1 \times 10^{5}$ mononuclear cells from severely burned patients to triplicate cultures containing $2 \times 10^{5}$ cells from a highly responsive normal responder and $1 \times 10^{5}$ mitomycin treated normal stimulator cells was assessed. The bars represent percentage decrease of the normal MLR when cells from burn patients are added at various times after injury.
TABLE IV

Difference between Observed Values* in Cultures with Added Cells and the Sums of the Partial Reactions

\begin{tabular}{cccc}
\hline \multicolumn{4}{c}{ Source of added mononuclear cells } \\
\hline $\begin{array}{c}\text { Group I } \\
\text { burn patients } \$\end{array}$ & $\begin{array}{c}\text { Group II } \\
\text { burn patients }\end{array}$ & $\begin{array}{c}\text { Group III } \\
\text { burn patients }\end{array}$ & $\begin{array}{c}\text { Normal } \\
\text { individuals }\end{array}$ \\
\hline & & & $\%$ \\
2,532 increase & 2,380 increase & 9,122 decrease & 1,372 increase $(+8)^{\mathbf{9}}$ \\
1,302 decrease & 1,814 decrease & 9,748 decrease & 3,373 increase $(+16)$ \\
1,501 decrease & 2,057 decrease & 9,875 decrease & 468 decrease $(-6)$ \\
1,941 decrease & 2,659 decrease & 10,831 decrease & 737 decrease $(-10)$ \\
& & 11,007 decrease & 810 decrease $(-11)$ \\
& & 11,766 decrease & 920 decrease $(-9)$ \\
& & 15,322 decrease & \\
\hline
\end{tabular}

* $\Delta$ Counts per minute ${ }^{3} \mathrm{H}-\mathrm{TdR}$ of sum of the partial reactions minus $\mathrm{R} \times \mathrm{S}$ $x$ added cells $\left(10^{5}\right)$.

† $R \times S_{m}+R \times P_{m}+P \times R_{m}+P \times S_{m}$, expressed as $\Delta$ counts per minute ${ }^{3} H-T d R$ incorporation.

Cells collected at 4-7 d after injury for all burn patients.

Percentage of difference between observed counts per min and Ipartial reactions.

patients who responded well to normal stimulators 1$2 \mathrm{~d}$ after burn were poorly responsive 7-8 $\mathrm{d}$ after injury (Table V). Data produced in experiments examining the ability of cells of group III patients to stimulate normal individuals in a one-way MLR were more complex. The amount of normal responder blastogenesis stimulated by the same patient appeared to vary from experiment to experiment. The stimulator capacity of group III cells decreased late in the suppressive period. We examined the mitomycin sensitivity of our suppressor cell. As illustrated in Table V, suppressor cells from group III patients were sensitive to mito-

TABLE V

Correlation of Patient Suppressor Cell Sensitivity to Mitomycin* with Stimulator Activity of Patient Cells in MLR $\downarrow$

\begin{tabular}{rrrrrrr}
\hline \multirow{2}{*}{$\begin{array}{c}\text { Day } \\
\text { after } \\
\text { injury }\end{array}$} & $\begin{array}{c}\text { Suppression } \\
\mathrm{P} \S\end{array}$ & $\begin{array}{c}\text { Suppression } \\
\mathrm{P}_{\mathrm{m}}\end{array}$ & $\mathrm{R} \times \mathrm{P}_{\mathrm{m}}$ & $\mathrm{R} \times \mathrm{S}_{\mathbf{m}}$ & $\mathrm{P} \times \mathrm{R}_{\mathbf{m}}$ & $\mathrm{P} \times \mathrm{S}_{\mathbf{m}}$ \\
\cline { 5 - 8 } & $\%$ & $\%$ & & & & \\
& & & & & & \\
5 & 70 & 32 & 11,247 & 10,879 & 4,822 & 654 \\
7 & 73 & 75 & 4,250 & 11,322 & 242 & 196 \\
5 & 57 & 18 & 2,988 & 11,292 & 3,888 & 3,732 \\
8 & 62 & 58 & 2,933 & 9,632 & 1,532 & 286 \\
12 & 26 & 0 & 3,558 & 7,182 & 4,123 & 2,807 \\
& & & & & & \\
5 & 74 & 42 & 13,490 & 10,345 & 1,775 & 955 \\
9 & 66 & 56 & 2,624 & 16,376 & 1,056 & 648 \\
2 & 11 & 2 & 17,773 & 25,254 & 18,335 & 1,900 \\
8 & 79 & 18 & 5,920 & 11,287 & 2,764 & 623 \\
\hline
\end{tabular}

* Cells from group III patients incubated with $0.25 \mu \mathrm{g}$ mitomycin C before addition to cultures containing normal one-way MLR combinations.

t Mitomycin-treated patient cells stimulating normal responder cells.

$\S$ Decrease in $\Delta$ counts per minute caused by addition of patient cells without mitomycin treatment $(P)$ or with treatment $\left(P_{m}\right)$. 
mycin C treatment at the onset of suppressor activity but resistant at later time periods. The mitomycin $\mathrm{C}$ sensitivity of these patients' suppressive cells appears to correlate well with their stimulatory ability for normal responders in a one-way MLR. As the data from the second patient in Table V illustrates, this correlation was often obscured because minimal genetic differences between patient and normal responder resulted in an originally low level of proliferation. Mitomycin controls were always included and in no instance was the resistance of the suppressive cells to mitomycin $\mathrm{C}$ because of improper treatment.

\section{DISCUSSION}

Septicemia is the major cause of morbidity in burn patients. A variety of in vitro and in vivo assays suggest that various parameters of immunocompetence are compromised by thermal injury (3-7). In particular, $\emptyset$ and T-cell function and number seem to be adversely affected by burns (8-12). Although MLR responses, skin graft rejection, and cell-mediated cytotoxicity all appear to decrease after burn trauma, the PHA response of burn patients' cells has been reported to increase after injury $(15,16)$. Some experimenters have reported that cell division by the leukocytes of burn patients increases in general, resulting in a false impression of increased mitogen-stimulated blastogenesis (24). This study demonstrates that a certain proportion of severely burned patients actually shows decreased responsiveness to PHA.

Earlier investigations probably did not detect the decreased PHA responses of this patient subset for the following reasons. (a) The patients were not studied individually and time-related changes in their individual PHA response level were not determined. (b) The previous studies assayed unseparated (25) or semiseparated (24) leukocyte populations containing large numbers of polymorphonuclear cells (26). These polymorphonuclear cells often rapidly divide and die in cultures possibly causing the high levels of ${ }^{3} \mathrm{H}-\mathrm{TdR}$ incorporation seen in the unstimulated (no mitogen) cultures of previous studies (27). (c) The mitogen techniques used were often different from classical methodology (21). (d) Burn patients were often not categorized by severity of injury and individuals with $0-95 \%$ third degree burns were examined as one group (24). Burn patients' mitogen responses were averaged and compared to averaged normal data, and the decreased responses of a small subset were obscured by a larger subset of patients with increased responses (28).

In this study, Ficoll-Hypaque purification decreased PMN contamination, cell viability was high, and low background levels were observed $(<3,000 \mathrm{cpm})$. Rather than averaging patient data, each individual served as his own control. Other recent studies support our data showing decreases in mitogen responses of burn patients' cells $(29,30)$. Our patients were retrospectively grouped into three categories on the basis of their clinical course. Although both group II and III patients developed infections, only group III patients had recurrent septic episodes, and decreased PHA responses were also detected only in group III patients. If massive cell death was the cause of this result, cells from all three patient groups or at least from group II and III should have shown decreased PHA responses. Only mononuclear cells from group III burn patients showed depressed PHA responses and developed significant suppressive activity.

With a modification of the classical MLR system, we detected suppression by measuring reduced proliferation of a normal responder-stimulator combination caused by addition of patient cells. It might be contended that our MLR system detects spurious suppressive activity. Comparing the sum of the proliferation by partial reactions in separate cultures to that in cultures containing three cells $\left(R \times S_{m} \times P\right)$, however, did not show significant differences if normal cells, group I cells, or group II patients' cells were added as the third party cells (Table IV). These results argue against the suggestion that cell death or differences in allogeneic stimulation is producing spurious suppression. Only addition of group III patient cells suppressed the normal one-way MLR response. Cells from group III patients were not initially suppressive but only became so at 4-7 d after thermal injury. These data also support the conclusion that a real effect of thermal injury on mononuclear cells is being detected.

In agreement with data from previous studies (19, 20 ), group III patient cells were uniformly poor responders in the MLR system. This poor immune response might have resulted because the normal individual's cells used as stimulators were too genetically similar to the patients' cells (23). Because the patients were not HLA typed, this probably did occur in some cases. It was also possible to demonstrate, however, that those group III patients' cells who initially responded well in a one-way MLR, lost that responder ability concomitant with their development of suppressive activity (Table V). The use of a known, highly reactive responder and stimulator in a normal one-way MLR as an indicator system for patient cell suppressive activity has the advantage of circumventing the need for HLA typing. Although the suppressive activity detected in these experiments appears to be nongenetically restricted in most cases, the simultaneous presence of an additional, undetected, genetically restricted suppressor is not eliminated. A genetically restricted suppressor cell (31) would be detected in our system only in cases where the normal responder and the burn patient shared HLA type. This may explain 
our observing only $60-70 \%$ suppression of the normal response.

Analysis of the capacity of cells from group III patients to stimulate normal responder cell proliferation in a one-way MLR was more difficult. Not only can the degree of HLA incompatibility affect results (23), but the stimulator capacity of group III patients' cells also appeared to depend on the mitomycin $\mathrm{C}$ sensitivity of the suppressor cell activity in the population. The suppressor cell activity of group III patient cells appears to be mitomycin sensitive during the 4- to 6-d period and resistant at later periods. This shifting mitomycin sensitivity of the suppressive cell activity may provide a clue to the identity of the suppressive cell. Human T suppressor cells have been demonstrated that are both mitomycin C sensitive and resistant (32-34). Suppressive monocytes have also been demonstrated in humans and are usually mitomycin resistant (35-37).

Our preliminary experiments appear to indicate that the early suppressive activity can be removed by depleting the mononuclear cell population of erythrocyte-rosetting cells as described by Lohrmann et al. (38), implicating a $\mathrm{T}$ cell as mediating the suppressive activity. Macrophage defects, however, have been repeatedly demonstrated in burn patients $(11,12)$. One nonspecific murine $T$ suppressor cell has been characterized as having $\Phi$ for target cells (27). Consequently, we cannot rule out a $\emptyset$ defect developing concomitant with or as a result of a $T$ suppressor cell. The change in mitomycin sensitivity that we detected could implicate two suppressive cells or a shift in suppressor cell types.

Severely burned patients appear to fall into two major categories: those that have infectious complications, and those with an uneventful clinical course. Those patients that experience infectious complications can be further divided into those who contain their infections and those who appear to have reduced resistance. Depression of mitogen responsiveness appears to identify that subset of patients who will later be unable to contain septic episodes. This decreased mitogen responsiveness does not appear until 4-5 d after injury and predates any clinical evidence of sepsis by 3-5 d. Concomitant with their depressed PHA responsiveness, cells from this same subset of burn patients express suppressive activity. Whether the same mononuclear cell(s) is mediating both PHA decreases and suppression of normal MLR is being investigated. The nature and action of the suppressive cell(s) which appears after burns is also being examined.

\section{ACKNOWLEDGMENTS}

This work was supported by USARMRDC contract DAMD 17-77-C-7012 and U. S. Public Health Service research grant GM 18740 .

\section{REFERENCES}

1. Krizek, Th. J., and D. V. Cossman. 1972. Experimental burn wound sepsis: variation in response to topical agents. J. Trauma. 12: 553.

2. Baxter, C. 1974. The current status of burn research. J. Trauma 14: 1 .

3. Howard, R. J., and R. L. Simmons. 1974. Acquired immunologic deficiencies after trauma and surgical procedures. Surg. Gynecol. Obstet. 139: 771-782.

4. Kohn, J. 1972. Abnormal immune response in burns. Postgrad. Med. J. 48: 335-337.

5. Markley, K., and E. T. Smallman. 1977. Effect of thermal trauma on numbers and function of $\mathrm{T}$ and $\mathrm{B}$ cells from mouse spleen. Int. Arch Allergy Appl. Immunol. 54: 238-246.

6. Rapaport, R. T., and R. J. Bachvaroff. 1976. Kinetics of humoral responsiveness in severe thermal injury. Ann. Surg. 184: 51-59.

7. Miller, C., and D. Trunkey. 1977. Thermal injury: defects in immune response induction.J. Surg. Res. 22: 621-625.

8. Niklasson Per M., and R. Williams. 1973. Studies of peripheral blood T- and B-lymphocytes in acute infections. Infect. Immun. 9: 1-7.

9. Markley, K., E. T. Smallman, and L. A. LaJohn. 1977. The effect of thermal trauma in mice on cytotoxicity of lymphocytes. Proc. Soc. Exp. Biol. Med. 154: 72-77.

10. Neilan, B. A., L. Taddenini, and R. G. Strate. 1977. T lymphocyte rosette formation after major burns. JAMA (J. Am. Med. Assoc.). 238: 493-496.

11. Smith, C. W., and A. S. Goldman. 1972. Selective effects of thermal injury on mouse peritoneal macrophages. Infect. Immun. 5: 938-941.

12. Altman, L. C., C. T. Furukawa, and S. J. Klebanoff. 1977. Depressed mononuclear leukocyte chemotaxis in thermally injured patients. J. Immunol. 119: 199-205.

13. Munster, A. M. 1976. Post-traumatic immunosuppression is due to activation of suppressor T cells. Lancet. I: 1329. (Abstr.)

14. Ninnemann, J. L., N. A. Seaver, and J. C. Fisher. 1978. Prolonged human allograft survival due to spontaneous immunosuppression following thermal injury. Transplantation (Baltimore). 25: 69.

15. Leguit, P., A. Meinesz, W. P. Zeijlemaker, P. T. A. Schellekens, and V. P. Eijsvooge. 1973. Immunological studies in burn patients. I. Lymphocyte transformation in vitro. Int. Arch. Allergy Appl. Immunol. 44: 101-121.

16. Mahler, O., and J. R. Batchelor. 1971. Phytohaemagglutinin transformation of lymphocytes in burned patients. Transplantation (Baltimore). 12: 409-411.

17. Winger, L. A., P. C. Nowell, and R. P. Daniele. 1977. Sequential proliferation induced in human peripheral blood lymphocytes by mitogen II. Suppression by PHA activated cells. J. Immunol. 118: 1768-1773.

18. Sampson, D., C. Grotelueschen, and H. M. Kauffman. 1975. The human splenic suppressor cell. Transplantation (Baltimore). 20: 362-367.

19. Sakai, H., J. C. Daniels, G. A. Beathard, S. R. Lewis. J. B. Lynch, and S. E. Ritzmann. 1974. Mixed lymphocyte culture reaction in patients with acute thermal burns. J. Trauma. 14: 53-57.

20. Munster, A. M., K. Eurenius, R. M. Katz, L. Canales, F. D. Foley, and R. F. Mortensen. 1973. Cell-mediated immunity after thermal injury. Ann. Surg. 177: 139-143.

21. Oppenheim, J. T., and B. Schecter. 1976. Lymphocyte transformation. In Manual of Clinical Immunology. N. Rose and H. Freidman, editors. American Society for Microbiology, Washington, D. C. 1st edition. 81-94. 
22. Boyum, A. 1968. Isolation of mononuclear cells and granulocytes from human blood. Isolation of mononuclear cells by centrifugation of granulocytes by combining centrifugation and sedimentation. Scand. J. Clin. Lab. Invest. Suppl. 21: 77-90.

23. Dupont, B., J. A. Hansen, and E. J. Yunes. 1976. Human mixed lymphocyte culture reaction: genetics, specificity and biological implications. Adv. Immunol. 23: 107-149.

24. Daniels, J. C., H. Sakai, E. Cobb, S. R. Lewis, D. Larson, and S. E. Ritzmann. 1971. Evaluation of lymphocyte reactivity studies in patients with thermal burns.J. Trauma. 11: $595-601$.

25. Daniels, J. C., E. K. Cobb, S. R. Lewis, D. L. Larson, and S. E. Ritzmann. 1970. Increased nucleic acid synthesis patterns in lymphocytes from patients with thermal burns. Surg. Gynecol. Obstet. 130: 783-788.

26. Ford, W. L. 1976. The preparation and labelling of lymphocytes. In Handbook of Experimental Immunology. D. M. Weir editor. Blackwell Scientific Publications Ltd., Oxford, England. 2: 397-419.

27. Waithe, W. J., and K. Hirsher. 1978. Lymphocyte response to activators. In Handbook of Experimental Immunology. D. M. Weir, editor. Blackwell Scientific Publications Ltd., Oxford, England. 2: 537-552.

28. Daniels, J. C., H. Sakai, and S. E. Ritzmann. 1975. Lymphoid response of the burn patient. South Med.J. 68: 865-870.

29. Altman, L. C., and C. Furukawa. 1978. Lymphocyte transformation to antigens and mitogens in patients with thermal injury. Proceedings 10th Annual American Burn Association Meeting. Birmingham, Alabama. 56-57.

30. Constantian, M. B. 1978. Association of sepsis with an immunosuppressive polypeptide in the serum of burn patients. Ann. Surg. 188: 209-215.

31. McMichael, A. J., and T. Sasazuki. 1977. A suppressor T cell in the human mixed lymphocyte reaction.J. Exp. Med. 146: $368-380$.

32. Hallgren, H. M., and E. J. Yunes. 1977. Suppressor lymphocytes in young and aged humans. J. Immunol. 118: 2004-2008.

33. Siegal, F., and M. Siegal. 1977. Enhancement by irradiated $\mathrm{T}$ cells of human plasma cell production: dissection of helper and suppressor functions in vitro. $J$. Immunol. 118: 642-647.

34. Haynes, B. F., and A. S. Fauci. 1978. Activation of human B lymphocytes. III. Concanavalin A induced generation of suppressor cells of the plaque-forming cell response. J. Immunol. 199: 2281-2287.

35. Sibbitt, W. L., A. Bankhurst, and R. C. Williams. 1978. Studies of cell subpopulations mediating mitogen hyporesponsiveness in patients with Hodgkin's disease. $J$. Clin. Invest. 61: 55-63.

36. Berlinger, N. T., C. Lopex, and R. A. Good. 1976. Facilitation or attenuation of mixed luekocyte culture responsiveness by adherent cells. Nature (Lond.). 260: 145-156.

37. Broder, S., R. Humphrey, M. Durm, M. Blackman, B. Meade, C. Goldman, W. Strober, and T. Waldmann. 1975. Impaired synthesis of polyclonal (non-paraprotein) immunoglobulins by circulating lymphocytes from patients with multiple myeloma. Role of suppressor cells. N. Engl. J. Med. 293: 887-897.

38. Lohrmann, H-P., L. Novikovs, and R. G. Graw. 1974. Cellular interactions in the proliferative response of human $\mathrm{T}$ and $\mathrm{B}$ lymphocytes to phytomitogens and allogeneic lymphocytes. J. Exp. Med. 139: 1553-1567. 